\title{
Experimental Organism Keratinizing Cyst
}

National Cancer Institute

\section{Source}

National Cancer Institute. Experimental Organism Keratinizing Cyst. NCI Thesaurus. Code C161543.

A thin, uniform cyst wall composed of well differentiated, flattened squamous epithelium undergoing orderly maturation and filled with large amounts of keratin. 